\title{
Geologia
}

\section{Mudanças Morfológicas da Extremidade NE da Ilha Comprida (SP) nos Últimos Dois Séculos}

\author{
Daniel Rodrigues do Nascimento Jr.' (danielir@usp.br), Paulo Cesar Fonseca Giannini² (pcgianni@usp.br), \\ Ana Paula Burgoa Tanaka² (anapaulabtanaka@yahoo.com.br), \\ Carlos Conforti Ferreira Guedes' (ccfguedes@usp.br) \\ 'Programa de Pós-graduação em Geoquímica e Geotectônica - Instituto de Geociências - USP \\ R. do Lago 562, CEP 05508-080, São Paulo, SP, BR \\ ${ }^{2}$ Departamento de Geologia Sedimentar e Ambiental - Instituto de Geociências - USP, São Paulo, SP, BR
}

Recebido em 19 de novembro de 2007; aceito em 07 de fevereiro de 2008

Palavras-chave: Ilha Comprida, registros históricos, morfologia, sedimentologia.

\section{RESUMO}

A Ilha Comprida, uma barreira holocênica constituída de alinhamentos de cordões litorâneos, tem experimentado mudanças morfológicas intensas nos últimos 200 anos em sua extremidade nordeste e arredores. Tais mudanças incluem o deslocamento do canal lagunar de Icapara para $\mathrm{N}$, variações na largura local da ilha, com surgimento de um pequeno campo de dunas transgressivo, aumento da largura do canal artificial do Valo Grande (em Iguape), e surgimento e desaparecimento de feições efêmeras (tais como uma proeminência na costa e um embaiamento lagunar). A morfodinâmica da extremidade nordeste da ilha obedece à interação entre deriva litorânea, marés e aporte fluvial através do rio Ribeira de Iguape. Destaca-se que a deriva litorânea para NE, inferida por análises sedimentológicas, é o principal fator de deslocamento do canal de Icapara nesse rumo, somado a um "efeito de meandramento" do canal. Este efeito seria gerado por interação entre regime de marés e aporte fluvial, através do qual a margem norte do canal (Iguape) comporta-se como dique marginal erosivo, enquanto a margem sul (Ilha Comprida) comporta-se como barra em pontal. Desta forma, ocorre remoção de areia em Iguape e redeposição na ponta da Ilha Comprida. Embora o crescimento da barreira para NE tenha atuado em escala milenar, sua velocidade aumentou de forma significativa após a abertura do Valo Grande em 1852, que se tornou fator de incremento sedimentar na desembocadura de Icapara.

Keywords: Ilha Comprida, historical records, morphology, sedimentology.

\section{ABSTRACT}

Ilha Comprida, a Holocene barrier built by alignments of littoral ridges, underwent intense morphologic changes in the past 200 years, mainly in its NE extremity. These changes includes northward shifting of the Icapara inlet, local variation of the width of the island, the formation of a small transgressive dunefield, an increase in the width of the Valo Grande artificial channel, and appearance and disappearance of ephemeral features such as a coastline prominence and a lagoonal embayment. The morphodynamics of the northeastern extremity of the island results from the interaction between littoral drift currents, tides, and fluvial sedimentary supply from the Ribeira de Iguape River. The remarkable northeastwards littoral drift, inferred by sedimentological analysis, is the main factor of the shifting of the Icapara channel in this direction, added to a "meandering effect" of the channel. This effect would be generated by interaction between the tidal regime and the fluvial sedimentary supply, such that the northward margin of the channel (Iguape) acts like a erosional levee, and the southward margin (Ilha Comprida) acts like a point bar. In this way, sand is removed at Iguape and deposited at the tip of Ilha Comprida. Even though the northeasterly growth of the barrier occurred over thousands of years its speed increased significantly after the opening of Valo Grande in 1852, which became factor influencing the sedimentary input at the Icapara inlet. 


\section{INTRODUÇÃO}

A barreira costeira denominada Ilha Comprida localizase no extremo sul do litoral de São Paulo e compreende o município de mesmo nome. Com cerca de 63 km de comprimento por 3 a 5 km de largura, dispõe-se em sentido SW-NE entre as desembocaduras do sistema lagunar Mar de Cananéia-Mar Pequeno, denominadas Cananéia e Icapara (Figura 1). Esta ilha é constituída predominantemente de sedimentos arenosos dispostos sob a forma de cordões litorâneos, que são expressão geomórfica de uma barreira progradante. A grande planície costeira à montante da ilha é drenada principalmente pelo rio Ribeira de Iguape, o maior a desembocar na costa paulista, próximo à extremidade nordeste da Ilha Comprida. O embasamento do entorno é constituído predominantemente de rochas proterozóicas granitóides e migmatíticas, além de paraderivadas do SGr. Açungui e algumas intrusivas alcalinas mesozóicas. A gê- nese desta barreira estaria associada à desaceleração da ascensão pós-glacial do nível relativo do mar (Guedes, 2003; Giannini et al., 2008, no prelo), cujo máximo teria ocorrido entre 5,1 e 5,4 ka AP (Angulo e Souza, 1999) (Figura 1).

Desde os tempos do Império no Brasil, o rio Ribeira de Iguape tem chamado atenção como potencial via de escoamento de produtos minerais, agrícolas e pesqueiros. A necessidade econômica de construir-se atalho entre o rio e o oceano, através da laguna, motivou a abertura do canal artificial chamado Valo Grande, obra concluída em 1852 (Geobrás, 1966). Juntos, esses dois fatores (importância econômica da região e posterior abertura do Valo Grande) motivaram o registro periódico da região e seu entorno através de relatos, mapas e cartas náuticas desde o fim do século XVIII. A análise desses registros evidencia mudanças morfológicas significativas no extremo nordeste da Ilha Comprida, onde muitas das quais podem ter sido favorecidas pela construção desse canal.

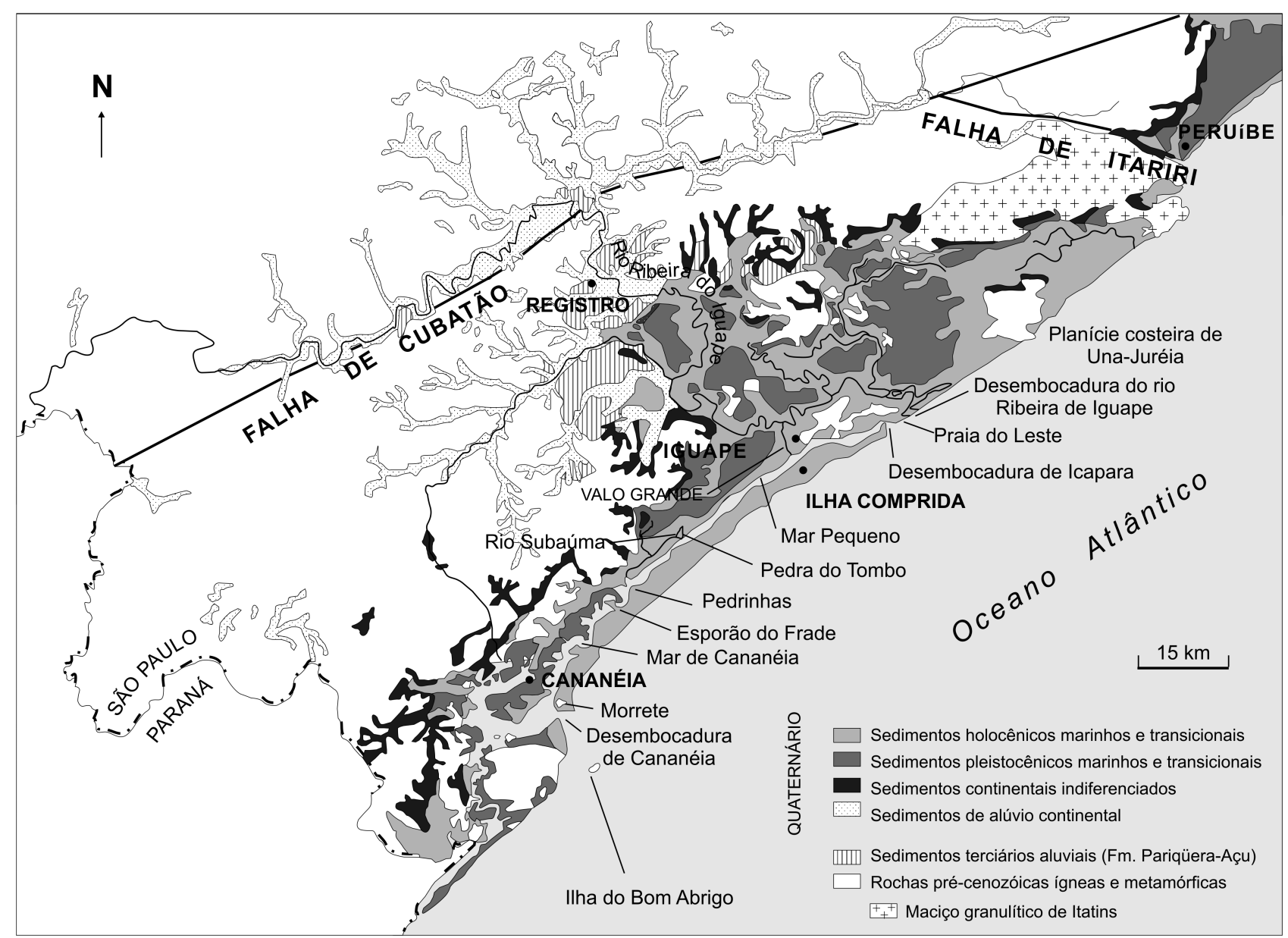

Figura 1. Mapa geológico da planície sedimentar cenozóica entre Cananéia e Peruíbe e arredores. Modificado e simplificado de IPT (1981). 
O objetivo principal deste artigo é demonstrar como se deu a evolução da extremidade nordeste da Ilha Comprida e seu entorno, do fim do século XVIII aos dias de hoje, através da compilação de registros históricos, descrições morfológicas de campo e análises sedimentológicas. Esta abordagem parte dos pressupostos de que há relação direta entre características texturais e mineralógicas das areias com a distribuição de morfologias no campo, e de que parte das morfologias encontradas atualmente reflete a dinâmica dessa relação ao longo do tempo.

\section{ÁREA DE ESTUDO}

A extremidade nordeste da Ilha Comprida compreende a interface entre três sistemas deposicionais ativos interdependentes: o marinho, o lagunar e o fluvial. O sistema lagunar na região possui desenvolvimento anômalo, que é reflexo da inexistência de uma gradação clara entre os sistemas marinho e fluvial. No entanto, depósitos lagunares sensu strictu, emersos, podem ser encontrados barreira adentro na margem interna da ilha.

Dois sistemas opostos de trem de ondas ocorrem na região: um de NE, associado a ventos alíseos, e outro de SE, relacionado a frentes frias (Tessler, 1988). Predominam alturas de onda (90\%) entre 0,5 e $2 \mathrm{~m}$, sendo $50 \%$ destas entre 1 e 1,5 m; o período médio das ondas durante ação dos ventos mais freqüentes (SE) é de 8,8 \pm 1 s (Geobrás, 1966). O predomínio de trens de ondas vindos desse quadrante induz transporte sedimentar por correntes de deriva litorânea, voltado dominantemente para rumo NE. Reflexo direto da influência dessas correntes se dá na distribuição holocênica de granulometria e minerais pesados de areias litorâneas recentes (Barcelos, 1975; Tessler, 1982, 1988; Souza, 1997; Nascimento Jr., 2006) e antigas (Tessler, 1988; Guedes, 2003).

Através de medições locais em estação maregráfica, Harari, França e Camargo (2004) verificaram forte ascensão do nível médio relativo do mar de aproximadamente $4 \mathrm{~cm} /$ década entre 1956 e 2000. A amplitude da maré média local varia entre 1,2 m (maré alta) e 0,25 m (maré baixa) (Mesquita e Harari, 1983); predomina, portanto, regime local de micromarés da classificação de Davies (1964).

No Mar Pequeno, próximo ao canal lagunar de Icapara, Tessler e Furtado (1983) identificaram estágios de crescimento de ilhas e esporões arenosos, e concluíram que a deposição sedimentar local obedece rumo preferencial coincidente com correntes de maré geradas na vazante, exceto nas proximidades do canal do Valo Grande. Ali, os mesmos autores detectaram redistribuição homogênea de sedimentos evidenciada por crescimento bidirecional das feições sedimentares, e afirmaram haver processo pronunciado de assoreamento no canal de Icapara (embora sem medir a taxa histórica de crescimento dessas feições).

\section{MÉTODOS}

Foi realizada compilação bibliográfica de registros históricos, mapas e cartas náuticas do levantamento prévio realizado no projeto denominado Complexo Valo GrandeMar Pequeno-Rio Ribeira de Iguape, pela empresa Geobrás Engenharia e Fundações S. A. (Geobrás, 1966), e da dissertação de Teles (1997). No primeiro trabalho, mapas e cartas datadas do último quarto do século XVIII (1776-1800?) ao ano de 1965 foram homogeneizadas à escala 1:25.000. No trabalho de Teles (1997), mapas do antigo Departamento de Águas e Energia Elétrica (DAEE) (ano de 1973, escala 1:25.000) e da Diretoria de Hidrografia e Navegação do Ministério da Marinha (DHN) (ano de 1982, escala 1:42.500) foram reunidos a um mapa de base aerofotográfica (ano de 1991, escala 1:25.000). Em adição ao material reunido destes trabalhos, um mapa foi realizado a partir de fotografia aérea do ano 2000 adquirido junto à empresa Aerofoto S. A., escala 1:25.000.

Ao longo do sistema praia-duna frontal da Ilha Comprida foi realizado levantamento morfológico com registro de fotografias e esboço das feições. Foram realizadas também amostragens de areia quilômetro a quilômetro, sobre a zona de espraiamento superior, somando um total de 63 amostras.

As amostras foram submetidas a ensaios de granulometria pela técnica convencional do peneiramento, em intervalos de 0,5 phi na escala de Wentworth-Krumbein. O tratamento dos resultados brutos de distribuição em massa incluiu contabilização do percentual de cada classe granulométrica e aquisição de parâmetros estatísticos da distribuição (diâmetro médio, assimetria e desvio-padrão), calculados pelo técnica analítica dos momentos de Pearson. Gráficos de dispersão com pontos ligados foram gerados para os parâmetros obtidos.

Da fração areia muito fina das amostras, tomadas de 2 em $2 \mathrm{~km}$, separaram-se minerais pesados pelo método do afundamento em bromofórmio $\left(\mathrm{CHBr}_{3}, \mathrm{~d} \sim 2,85 \mathrm{~g} / \mathrm{cm}^{3}\right)$. Destes, foram separados minerais magnéticos por fricção suave de ímã de mão envolto em capa de plástico. Por fim, realizouse confecção de seções delgadas desta última fração por impregnação de grãos ao bálsamo do Canadá natural, para quantificação de seu teor em minerais pesados transparentes ao microscópio petrográfico comum (contagem de pelo menos 100 grãos por lâmina).

Com base nos resultados de contagem, calculou-se a soma percentual de minerais ultra-estáveis (zircão, turmalina e rutilo) ou índice ZTR (Hubert, 1962). Para a soma percentual de minerais metaestáveis e instáveis (aqui abreviados índices MET e INS), foi adotada a classificação de Pettijohn (1957). Em adição, subdividiu-se a assembléia de minerais pesados em dois grupos, de comportamento hidráulico supostamente diferenciado: o primeiro reúne minerais tidos como "mais 
equidimensionais e densos” (alto equivalente hidráulico), e o segundo, minerais “mais alongados e menos densos" (baixo equivalente hidráulico) (Nascimento Jr., 2006). A distribuição dos índices de estabilidade mineral e de grupos minerais de diferente equivalente hidráulico foi ao final lançada em gráficos de dispersão com pontos ligados.

Para os gráficos obtidos de distribuições de freqüências de granulometria e minerais pesados, foram calculados índices de correlação linear (r). Para avaliar os resultados de r, o critério estatístico usado foi o nível de significância ou erro $\mathrm{I}(\alpha)$, que corresponde à probabilidade de rejeitar uma hipótese nula $\left(\mathrm{H}_{0}\right)$ verdadeira. Como $\mathrm{H}_{0}$, neste caso, afirma a inexistência de correlação significativa $(r \sim 0)$, $\alpha$ pode ser entendido como a probabilidade de aceitar-se correlação inexistente. Estimaram-se seus valores máximos por interpolação comparando o quociente t do teste de regressão unicaudal de distribuição (t de Student). No presente estudo, admitiram-se resultados de correlação linear com nível menor ou igual a 0,4 (chance de quatro em dez de rejeitar hipótese nula verdadeira).

\section{RESULTADOS}

\section{Registro histórico, cartográfico e aerofotográfico}

Relatos do século XVII referem-se ao desembarque de produtos por embarcações pequenas no antigo "Porto Velho da Ribeira”, em Iguape, localizado em frente ao trecho lagunar do Mar Pequeno, próximo à extremidade SW do Morro de Icapara (Geobrás, 1966). Nessa época, a Ilha Comprida era, supostamente, quase uma dezena de quilômetros menor e o porto situava-se numa região mais aberta ao mar e, portanto, menos assoreada. Navegando rio Ribeira de Iguape abaixo, as embarcações que chegavam a uma distância em linha reta de $3 \mathrm{~km}$ do porto eram obrigadas a continuar viagem por mais $53 \mathrm{~km}$ através dos meandros do rio, do oceano e da desembocadura lagunar para, só então, já na laguna, fazer o desembarque em Iguape. No referido ponto de maior proximidade do porto, uma inflexão em "V" desviava o Ribeira de Iguape de desembocar na laguna, e próximo dele, encontrava-se uma "grande lagoa em forma de meia circunferência” (Geobrás, 1966). Em 1827, tiveram início as obras de criação de um atalho através desta "lagoa”, mais precisamente um lago de meandro abandonado, através da abertura de um canal chamado "Valo do Rocio", posteriormente designado "Valo Grande” (Geobrás, 1966; Teles, 1997). A conclusão da obra, com estabelecimento de conexão entre rio e laguna (Figura 1), data de 1852.

Desde então, numerosas mudanças morfológicas associadas a esta construção artificial passaram a ser registradas, levando, também, a diversas tentativas de minimização de efeitos indesejados. Os problemas apontados como advindos da abertura do Valo Grande incluem erosão e inundação de áreas antes cultiváveis e habitadas no entorno do canal, assoreamento do Mar Pequeno (Geobrás, 1966) e do porto de Iguape e destruição quase total da praia do Leste, situada na face sul-sudeste da Ilha de Iguape (Figura 1). Em 1978, o Valo Grande foi fechado por uma barragem de blocos de rocha capeados por lama, para estabelecer tráfego de veículos terrestres entre a ilha de Iguape e o continente (Teles, 1997). A partir daí, galgamentos de água doce e rompimentos parciais começaram a ocorrer esporadicamente a montante da barragem, especialmente após chuvas intensas (DAEE 1989 apud Teles, 1997; Pisetta, 2006). Em 1995, após mais um evento de chuvas fortes, a barragem rompeuse em definitivo e o canal do Valo Grande alargou e tornouse novamente ativo (Pisetta, 2006).

A comparação entre fotos aéreas de 1962 e 2000 possibilitou verificar mudança na posição da desembocadura lagunar de Icapara, que se deslocou 912,5 m para NE, em detrimento da praia do Leste e planície de cordões adjacentes, situada na margem leste da ilha de Iguape. No mesmo período, a extensão dessa praia diminuiu aproximadamente $570 \mathrm{~m}$, podendo em parte ter ocorrido por influência da migração abrupta da desembocadura do rio Ribeira de Iguape para SW (Bentz e Giannini, 2003; Bentz, 2004) (Figura 2).

O estudo integrado de mais de 130 anos de registro histórico de mudanças ocorridas no extremo nordeste da Ilha Comprida encontra-se ilustrado nas Figuras 3 e 4 . Além do deslocamento do canal de Icapara rumo NE (que do fim do século XVIII ao ano 2000 foi de cerca de 5,5 km), destacamse também:

1. grande variação da largura na extremidade nordeste da Ilha Comprida, com destaque para a região correspondente ao atual campo de dunas ativo;

2. existência de feições intermitentes, como um antigo embaiamento lagunar imediatamente a sul do morro de Icapara ("lagoa” Gapara), e surgimento (entre 1938 e 1943) e desaparecimento (entre 1991 e 2000) de um esporão arenoso na praia da Ilha Comprida (entre os km 59 e 60, rumo SW-NE).

As medições e registros cartográficos permitiram ilustrar, graficamente, a evolução da largura do Valo Grande, a variação da largura da extremidade nordeste da Ilha Comprida (região do campo de dunas ativo), a comparação entre o crescimento da ponta nordeste da Ilha Comprida e o recuo rumo N (redução) da planície de cordões da Ilha de Iguape (erosão da praia do Leste), e a comparação entre o deslocamento rumo NE da Ilha Comprida e a evolução da largura da sua extremidade nordeste (Figura 5). O resultado aponta para acentuado aumento da largura do canal do Valo Grande entre 1870 e 1910 (cerca de 3,5 m/ano em média: Figura 5A), 

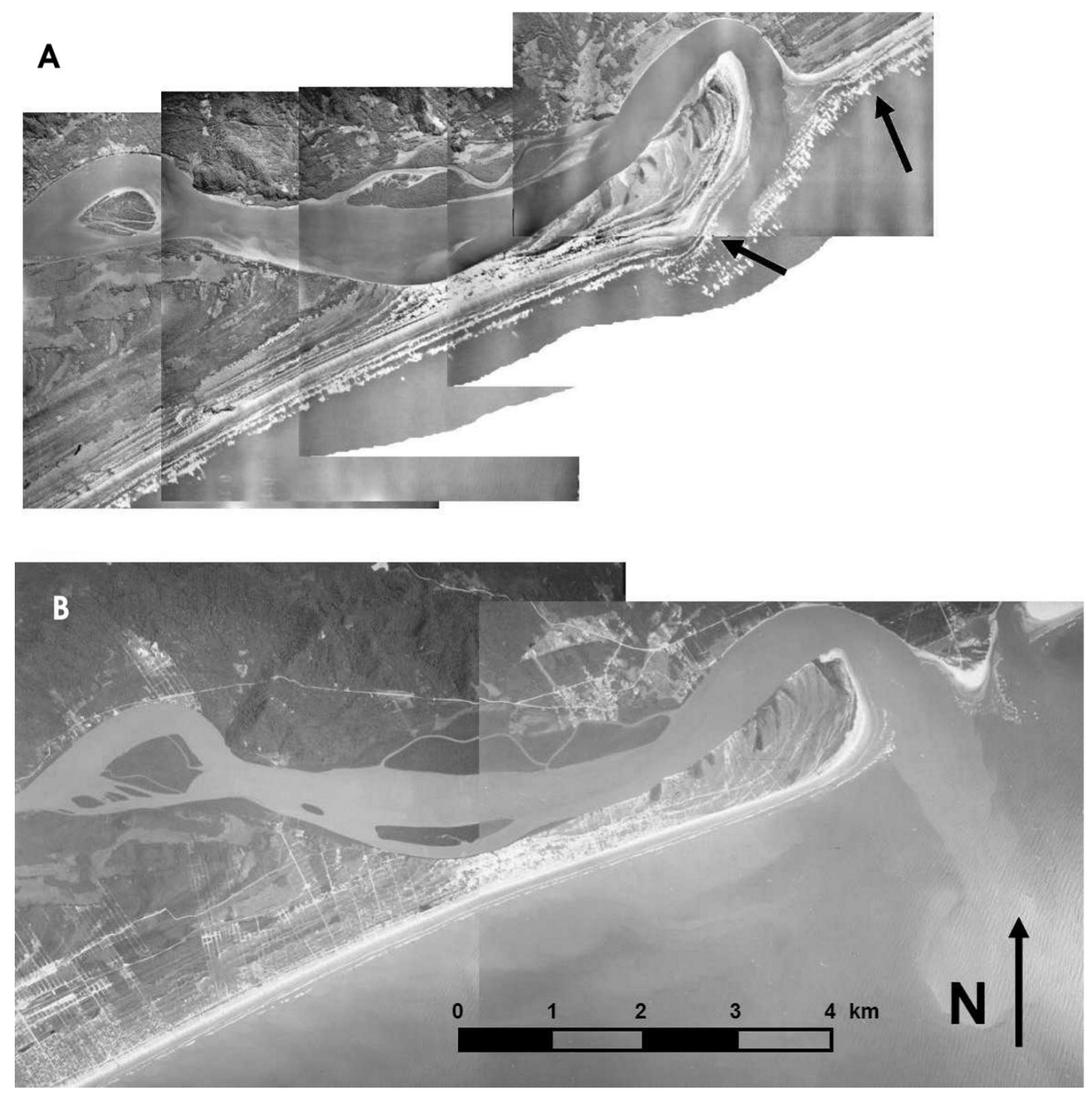

Figura 2. Fotografias aéreas do extremo nordeste da llha Comprida (seta inferior) e praia do Leste (seta superior), anos de 1962 (A) e 2000 (B). Notar, entre as datas, o deslocamento da desembocadura de lcapara para NE, a redução da planície de cordões ao interior da praia do Leste, e desaparecimento de esporão arenoso na praia de llha Comprida. 

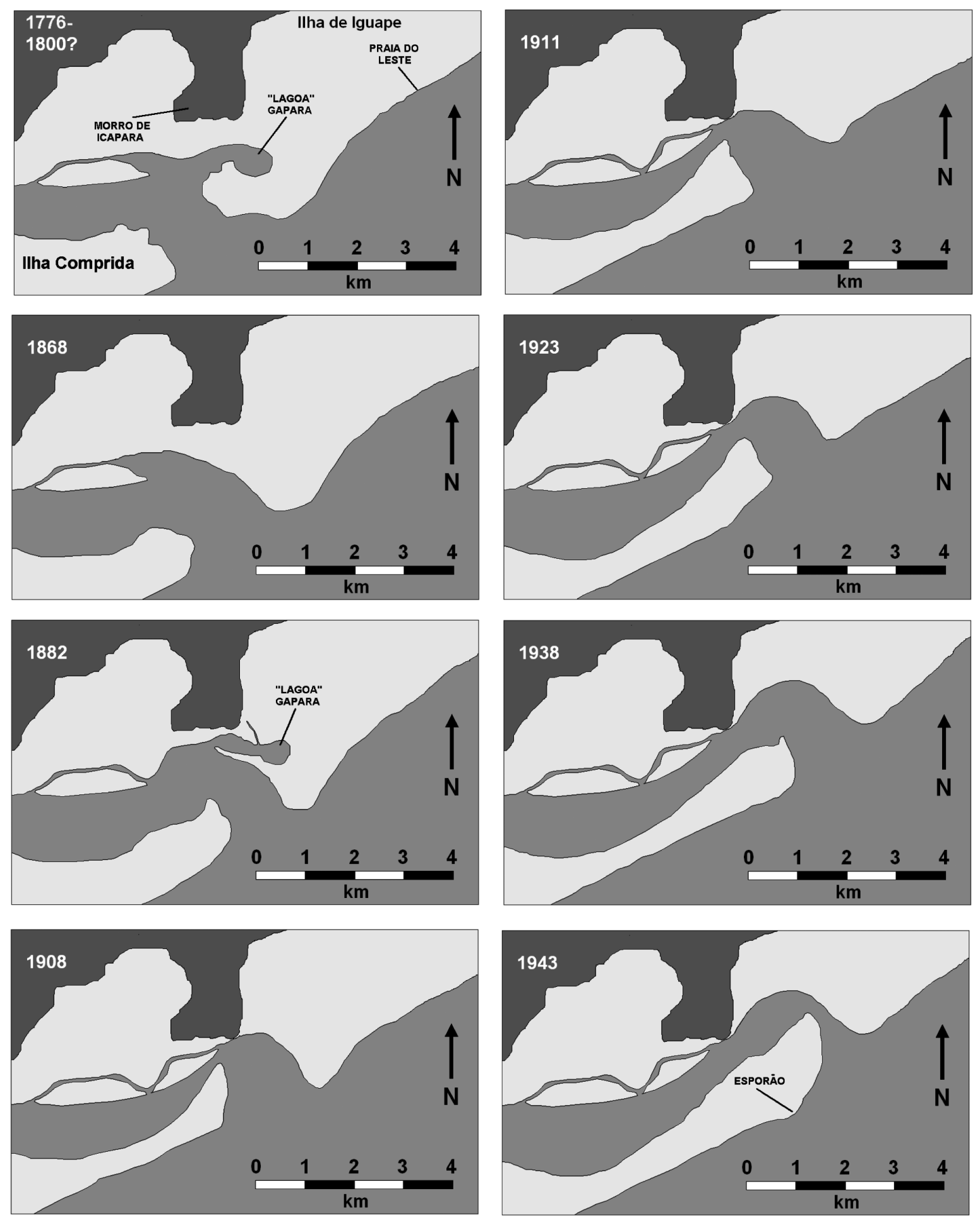

Figura 3. Registro histórico de mudanças ocorridas no entorno do extremo nordeste da llha Comprida, entre o final do século XVIII (1776-1800?) e o ano de 1943. O Valo Grande, não contemplado nestes recortes dos mapas, encontra-se cerca de 7 km a oeste. Compilado de Geobrás (1966), Teles (1997) e este trabalho. 

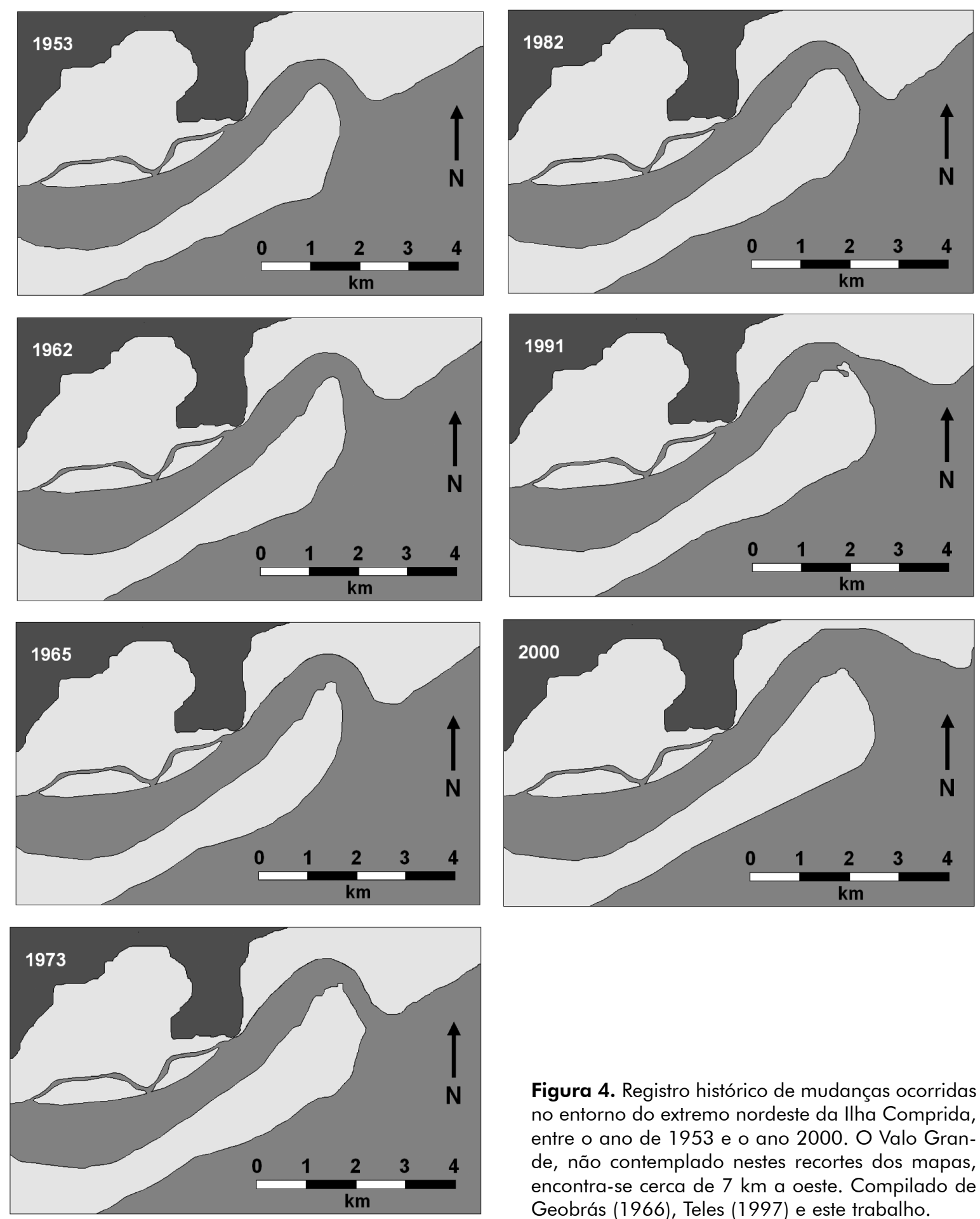

Figura 4. Registro histórico de mudanças ocorridas no entorno do extremo nordeste da llha Comprida, entre o ano de 1953 e o ano 2000. O Valo Grande, não contemplado nestes recortes dos mapas, encontra-se cerca de $7 \mathrm{~km}$ a oeste. Compilado de Geobrás (1966), Teles (1997) e este trabalho. 
período grosso modo equivalente ao do surgimento e rápido estreitamento (cerca de 17,5 m/ano em média) da região correspondente a um campo de dunas ativo do extremo nordeste da ilha (entre os quilômetros 58 e 59, rumo NE). Quanto ao deslocamento da Ilha Comprida neste sentido, que acompanha a migração da margem norte do canal de Icapara, nota-se tendência de estreitamento da desembocadura lagunar verificada no déficit entre curvas de dispersão gráfica das distâncias percorridas pela ilha e pela margem do canal (Figura 5C) a partir de 1940, fato também notado nos mapas da Geobrás (1966) a partir desse ano (Figuras 3 e 4). Entre 1991 e 2000, porém, a largura do canal de Icapara aparentemente aumenta. Por fim, a variação da largura da Ilha Comprida na região do campo de dunas não aparenta relação clara com o deslocamento rumo NE da barreira (Figuras 5B e 5D), exceto talvez entre 1882 e 1908, período em que essa região se estabelece. Nesse intervalo, o "estrangulamento" desse trecho da ilha foi quase equivalente ao seu crescimento rumo NE (cerca de 30 m/ano no período).
Embora o canal do Valo Grande tenha exercido papel fundamental no crescimento longitudinal da ilha nas últimas décadas, o crescimento transversal (“engorda”) teve lugar de destaque nos primeiros anos após a abertura desse canal. Como visto, o morro de Icapara, maciço cristalino localizado na ilha de Iguape, aparentemente funcionava de obstáculo ao crescimento longitudinal da barreira para NE. Assim, a barreira só poderia acelerar seu crescimento longitudinal nesse sentido após “vencer” esse promontório através de crescimento lateral (Giannini et al., 2003a; Guedes, 2003). A abertura do Valo Grande, em 1852, pode ter sido o fator de incremento de aporte responsável pela aceleração da engorda lateral, seguido da retomada do crescimento longitudinal.

\section{Distribuição granulométrica e mineralógica}

Na praia da Ilha Comprida, predominam em média areias finas a muito finas (70\% e $30 \%$ de teor médio em massa, respectivamente), bem selecionadas (51\%) a muito bem
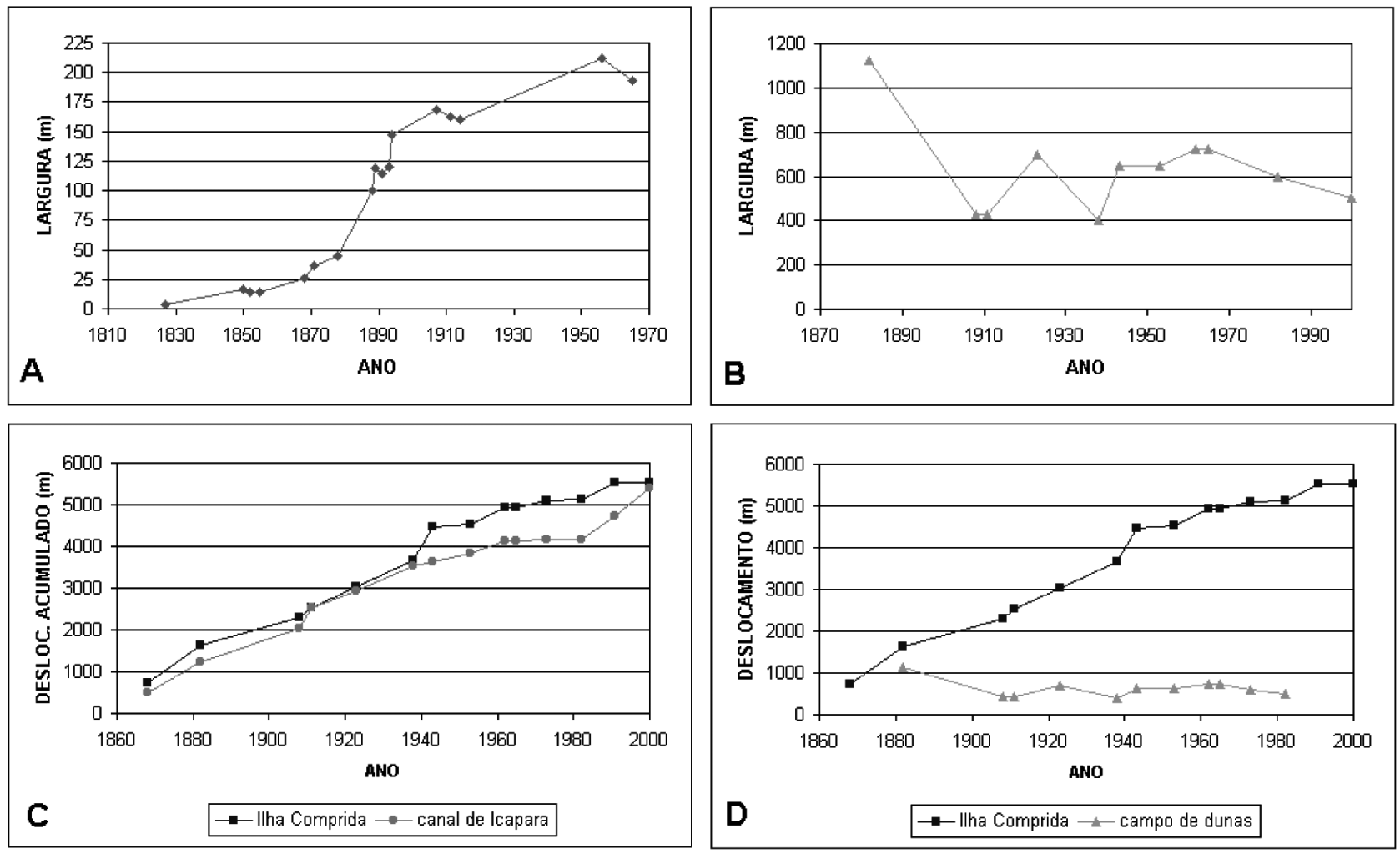

Figura 5. Gráficos de distribuição temporal dos registros de medições históricas compilados de Geobrás (1966), Teles (1997) e este trabalho. A. Evolução da largura do canal do Valo Grande. B. Variação da largura da extremidade nordeste da Ilha Comprida (região do campo de dunas ativo). C. Comparação entre o deslocamento acumulado rumo nordeste da llha Comprida e o recuo acumulado rumo norte da planície de cordões de lguape (na região da praia do Leste). D. Comparação entre o deslocamento acumulado rumo nordeste da llha Comprida e a evolução da largura da sua extremidade nordeste. 
selecionadas (49\%), e de assimetria negativa a muito negativa (54\% para o conjunto) (Figura 6 ).

Na Figura 6, verifica-se rumo NE tendência geral de afinamento, melhora do grau de seleção (diminuição do desvio-padrão) e assimetria mais negativa. Esta combinação de variações é concordante com um dos padrões indicadores de transporte segundo McLaren e Bowles (1985) e, portanto, sugestiva de deriva litorânea longitudinal predominante naquele sentido.

Na fração areia muito fina da praia, foi encontrado teor em massa de minerais pesados de 0,69\% em média, sendo que destes foram separados em média 3,79\% de minerais magnéticos. O teor médio em volume de minerais opacos, entre os pesados não-magnéticos, foi de 63,5\%. A assembléia de minerais pesados transparentes encontrada reflete claramente sua origem metamórfica a partir de rochas do Complexo Costeiro e do Supergrupo Açungui, além de uma provável contribuição a partir de sedimentos relíquias retrabalhados da plataforma continental adjacente (Giannini, 1987; Tessler, 1988). Além de zircão, turmalina e rutilo da assembléia ultra-estável (ZTR), incluem-se entre os metaestáveis epídoto, estaurolita, sillimanita, cianita, andaluzita, granada e monazita (ordem decrescente de abundância), e entre os instáveis, hornblenda, hiperstênio, tremolita e clinopiroxênios.

A análise dos índices de maturidade mineralógica permite observar tendência de decréscimo de ZTR de sudoeste para nordeste, com relativo enriquecimento em minerais instáveis (INS) (Figura 7). Em vista ao padrão geral de transporte sedimentar para NE evidenciado pela análise granulométrica, ocorreria aumento, dentro da fração areia muito fina, da quantidade relativa de minerais de elevada densidade e equivalente hidráulico, devido à redução da granulometria, dentro da mesma fração, no rumo da deriva longitudinal (Giannini et al., 1995; Nascimento Jr., 2006).

Os minerais pesados reunidos no grupo de alto equivalente hidráulico foram: zircão, rutilo, estaurolita, granada e monazita. O restante foi reunido no grupo de minerais de baixo equivalente hidráulico. Pelo confronto gráfico entre os dois grupos evidencia-se tendência, para NE, de aumento relativo do teor de minerais de baixo equivalente hidráulico (com concomitante redução no teor dos de alto equiva-
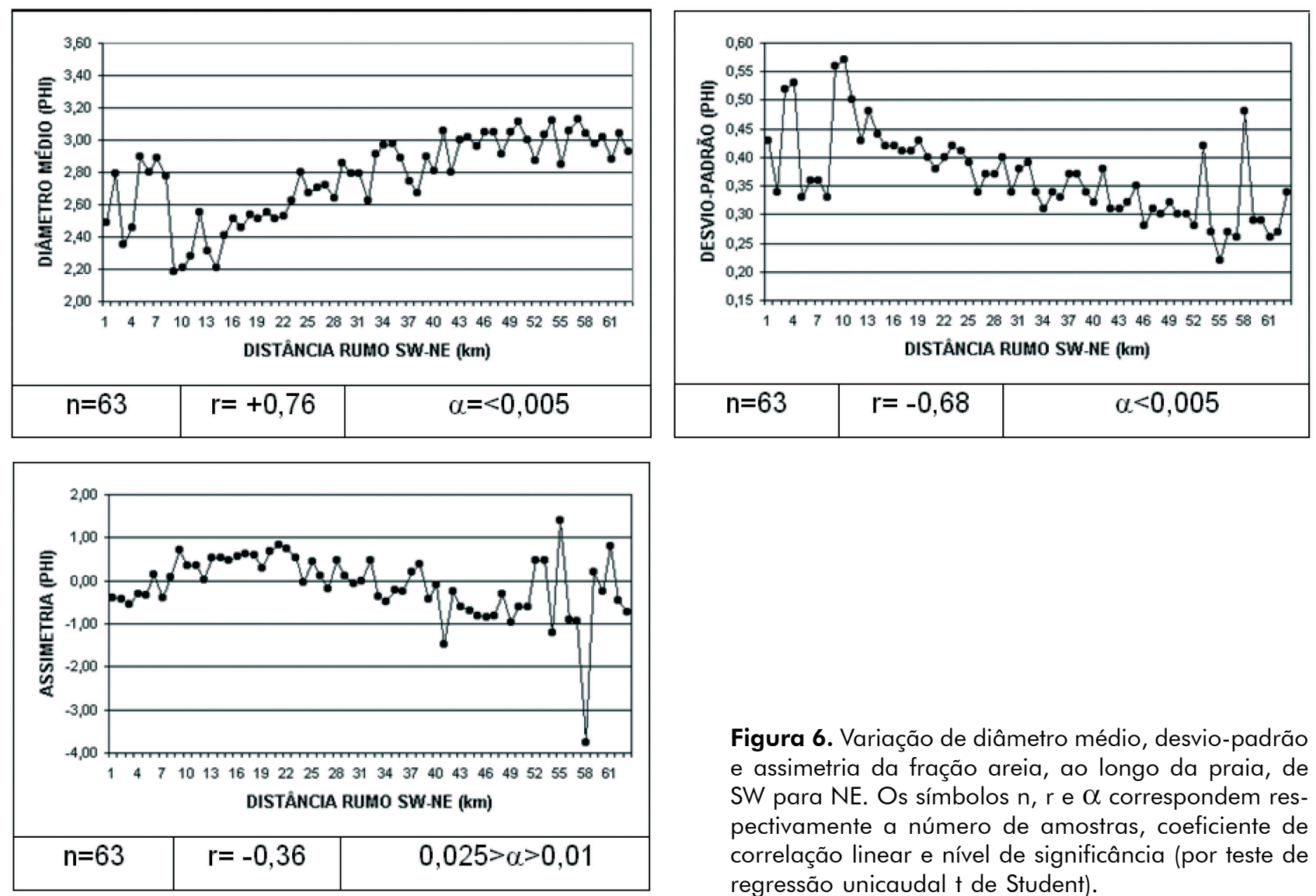

Figura 6. Variação de diâmetro médio, desvio-padrão e assimetria da fração areia, ao longo da praia, de SW para NE. Os símbolos $n, r$ e $\alpha$ correspondem respectivamente a número de amostras, coeficiente de correlação linear e nível de significância (por teste de regressão unicaudal t de Student). 

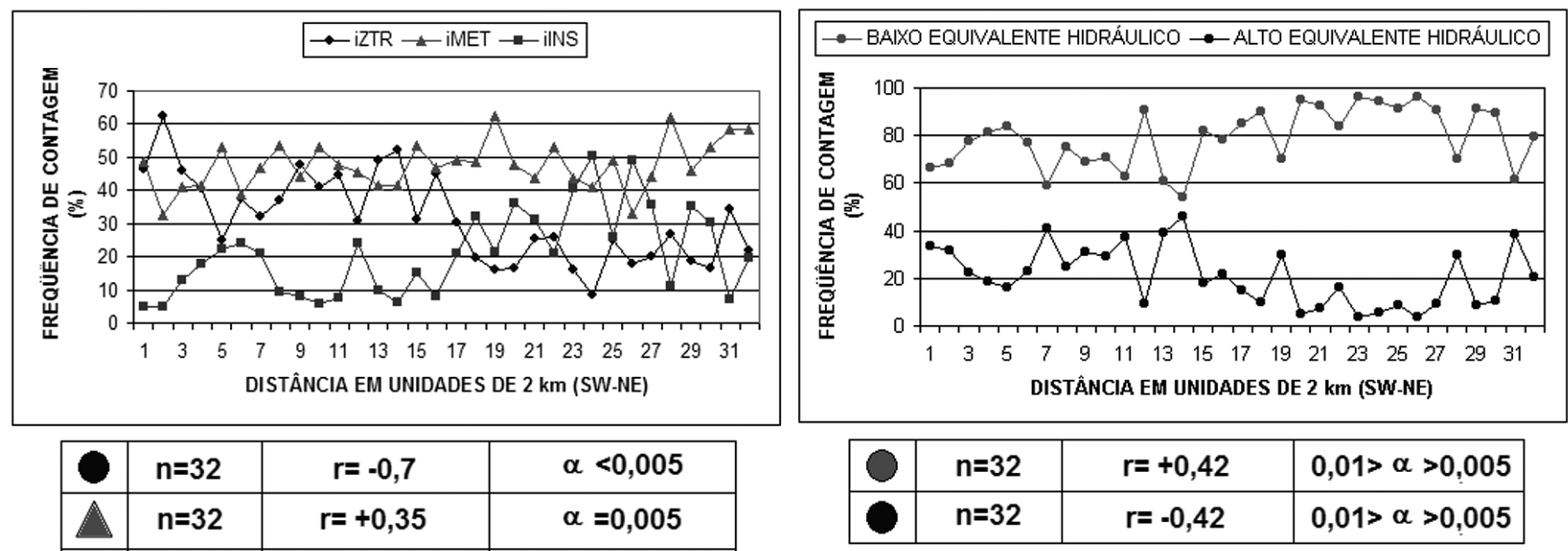

\begin{tabular}{|c|c|c|c|}
\hline & $\mathrm{n}=32$ & $\mathrm{r}=-0,7$ & $\alpha<0,005$ \\
\hline $\mathbb{N}$ & $\mathrm{n}=32$ & $\mathrm{r}=+0,35$ & $\alpha=0,005$ \\
\hline$\square$ & $\mathrm{n}=32$ & $\mathrm{r}=+0,51$ & $\alpha<0,005$ \\
\hline
\end{tabular}

Figura 7. Variação dos índices de estabilidade (à esquerda) e de somatórios de minerais pesados por agrupamento de "mais equidimensionais e densos" versus "mais alongados e menos densos" (à direita), para a praia de Ilha Comprida, em sentido de SW para NE. Os símbolos $n, r$ e $\alpha$ correspondem respectivamente a número de amostras, coeficiente de correlação linear e nível de significância (por teste de regressão unicaudal t de Student).

lente hidráulico). Novamente, o resultado é concordante com tendência de transporte sedimentar neste rumo, no caso, através da seleção hidráulica por forma e densidade das partículas em trânsito (Figura 7).

\section{DISCUSSÃO}

\section{Integração de resultados de morfologia e sedimentologia}

Entre as mudanças descritas para a extremidade nordeste da Ilha Comprida, destaca-se o deslocamento do canal de Icapara para NE. Por este fenômeno, quase 10\% do comprimento atual da barreira formou-se essencialmente nos últimos dois séculos, a uma taxa média aproximada de 27,5 m/ano. Datações LOE e ${ }^{14} \mathrm{C}$ realizadas em seus cordões mais internos (Guedes, 2003; Giannini et al., 2008, no prelo), abrangendo quase a totalidade do grande trecho restante (cerca de $55 \mathrm{~km}$ ), mostram que a maior parte da ilha formou-se a uma taxa aproximada de $20 \mathrm{~m} / \mathrm{ano}$. Isso mostra que, desde seu surgimento, a Ilha Comprida tem experimentado taxas relativamente altas de crescimento longitudinal para NE. Em adição, mostra também que houve aceleração dessa taxa de crescimento nas últimas décadas, provavelmente em função da abertura do canal artificial do Valo Grande a partir de 1852 (Nascimento Jr., 2006).

A análise da Figura 5 novamente faz ressaltar a influência desse canal nas modificações morfológicas observadas. O Valo Grande é, segundo Pisetta (2006), o principal agente de aporte de sedimentos em suspensão para o sistema lagunar, especialmente rumo ao canal de Icapara, e despeja aí cerca de 75\% da vazão do rio Ribeira de Iguape. Porém, no que se refere à carga de fundo arenosa, a erosão e retrabalhamento de sedimentos pré-existentes são de grande importância no suprimento à laguna, sendo insignificante a carga trativa advinda diretamente do rio (cujos sedimentos trazidos são principalmente pelíticos em suspensão). Para o ano de 1965, época em que a largura do canal já era comparável à atual (cerca de 200 m), Geobrás (1966) afirmava que o aporte de sedimentos na fração areia (transporte trativo de fundo) através do Valo Grande se dava mais pela erosão de depósitos mais antigos conseguinte de sua abertura. O mesmo mecanismo é defendido por Pisetta (2006), com base na distribuição de sedimentos de fundo da desembocadura de Icapara encontrada por Barcellos (2005). A referida distribuição de sedimentos indica predominância de "fundo intercalado por manchas de areia fina e de sedimento siltoso".

Erosão e remobilização de areias pelo fluxo do Valo Grande seriam concentradas especialmente nas margens deste canal, na margem lagunar junto à ilha de Iguape, e do canal artificial até a desembocadura de Icapara, ao longo do leito. No que se refere especificamente à desembocadura de Icapara, e ao próprio crescimento recente da ilha Comprida para NE, este efeito de remobilização de areias pré-existentes, estimulado pelo aumento de vazão devido ao Valo Grande, incluiria a dinâmica de meandramento do canal de Icapara, à semelhança de um canal fluvial. Este comporta- 
mento meandrante do canal de Icapara pode ser assinalado pelos seguintes argumentos:

a. sua curvatura em planta;

b. sua assimetria em perfil (Geobrás, 1966; Tessler, 1982);

c. o transporte sedimentar transversal ao canal com resultante para SW, isto é, rumo seu lado de declive mais suave (Ilha Comprida), confirmado por análise granulométrica segundo a metodologia de Gao e Collins (1992), realizada por Conti (apud Pisetta, 2006).

Desse modo, a margem norte do canal (Iguape), interna, comporta-se como dique marginal erosivo, enquanto a margem sul (Ilha Comprida), externa, comporta-se como barra em pontal. Por esta dinâmica, os sedimentos erodidos em Iguape são redepositados na Ilha Comprida, deslocando o canal de Icapara para norte (Figuras 3 e 4).

A efemeridade de algumas feições sedimentares, como a "lagoa” Gapara e o esporão do extremo nordeste da ilha (Figuras 3 e 4), reflete a intensa dinâmica sedimentar dessa área. O esporão pode ser observado em foto aérea de 1962 (distâncias 59 e 60 km rumo NE; Figura 2), onde se nota, em associação, deslocamento da quebra de trens de ondas rumo ao mar. Esse fato evidencia que a presença da projeção da linha de costa era acompanhada de elevação do fundo sedimentar na zona submersa, semelhante ao que ocorre hoje em dia no extremo sudoeste da ilha, onde Bonetti Filho e Furtado (1996) sugerem presença de um delta de maré vazante. Embora notado pela foto de 1962, o esporão neste trecho da ilha já se destacava em mapas a partir de 1943 (Figuras 3 e 4). Sua existência pode marcar um momento de deflexão para $\mathrm{N}$ da extremidade nordeste da ilha.

Com a retomada do rumo mais habitual de crescimento da ilha (NE), após 1962, este esporão entrou em erosão. Possíveis resquícios desta erosão, ainda em andamento na porção da praia correspondente à antiga projeção da linha de costa, são a presença de casas destruídas, hoje em plena face da praia (Figura 8A), e a existência de falésias vivas escavadas em terraços de dunas frontais (Figura 8B).

Cabe destacar a presença de um pequeno campo de dunas transgressivo ( $2 \times 0,5 \mathrm{~km}$ ) (Figura 9) em atividade entre as distâncias de 57 e 58 km (sentido SW para NE) na ilha, representante mais expressivo da terceira geração de dunas (“geração 3”) reconhecida por Giannini et al. (2008, no prelo) na Ilha Comprida. Seu estabelecimento reflete predomínio, ao menos temporário, de estoque excessivo de areia naquele ponto da costa. Este acúmulo excedente teria ocorrido num momento em que a deriva litorânea longitudinal desse trecho, até então bloqueada pelo morro de Icapara, começava a superar tal obstáculo. Desse modo, a iniciação do campo de dunas também marcaria a transição de um período de predomínio de “engorda” (aumento da largura) da ilha para o atual período de crescimento longitudinal intensificado. Esse trecho da ilha também corresponde ao de sua extremidade à época em que o Valo Grande foi aberto, segundo os mapas originalmente reunidos por Geobrás (1966). Outro fator favorável ao desenvolvimento do referido campo de dunas é de caráter morfológico: o trecho entre os quilômetros 57 e 60, que abrange o campo de dunas, é tido como região de maior estreitamento da ilha (Guedes, 2003). Mesmo considerando aporte eólico homogêneo ao longo da barreira, uma redução no espaço de acumulação poderia "saturar” areia em trecho reduzido, culminando no crescimento de um campo de dunas (Giannini, 2007; Giannini et al., 2008, no prelo; Sawakuchi, 2006).

O rumo de deslocamento do canal de Icapara é coincidente com a direção da corrente de deriva litorânea local, verificada nas distribuições granulométricas (regra de McLaren e Bowles, 1985) e mineralógicas das amostras de praia. Estudos sedimentológicos de Tessler (1988) e Guedes (2003) em cordões antigos (mais a SW) também apontam para deriva litorânea nesse sentido; em adição à comentada variação de idades, isto é indício de que esse padrão de transporte sedimentar marinho não deve ter se alterado de forma significativa, desde a formação da Ilha Comprida.

Através da dinâmica de meandramento do canal de Icapara, sedimentos erodidos da planície costeira (à retaguarda da Ilha Comprida) e da Ilha de Iguape, durante a maré vazante (com potencial incrementado após a abertura do Valo Grande) são retrabalhados e redepositados na ponta NE da barreira. Tal processo, também influenciado pela deriva litorânea, explica as distribuições sedimentológicas da extremidade nordeste da barreira.

\section{A evolução sedimentar da Ilha Comprida e a extremidade nordeste}

Com base em fotointerpretação, descrição de perfis em transectos, análises texturais e mineralógicas e datações (LOE e ${ }^{14} \mathrm{C}$ ), Giannini et al. (2003b, 2008, no prelo) e Guedes (2003) propuseram um modelo de evolução sedimentar para Ilha Comprida, no qual a importância relativa entre seus componentes de crescimento transversal e longitudinal é influenciada pela presença de um obstáculo (morro de Icapara). Seu modelo consta de quatro fases principais de crescimento, divididas em oito tempos. Embora atentassem para possibilidade de existência da "fase zero" da ilha (anterior ao crescimento progradante de seus cordões), os autores reconheceram não haver seu registro aparente tanto em superfície como subsuperfície.

De acordo com esse modelo, na fase 1 predominou crescimento para NE, pela adição de cordões litorâneos curvados para esse rumo, com pronunciado componente de “en- 

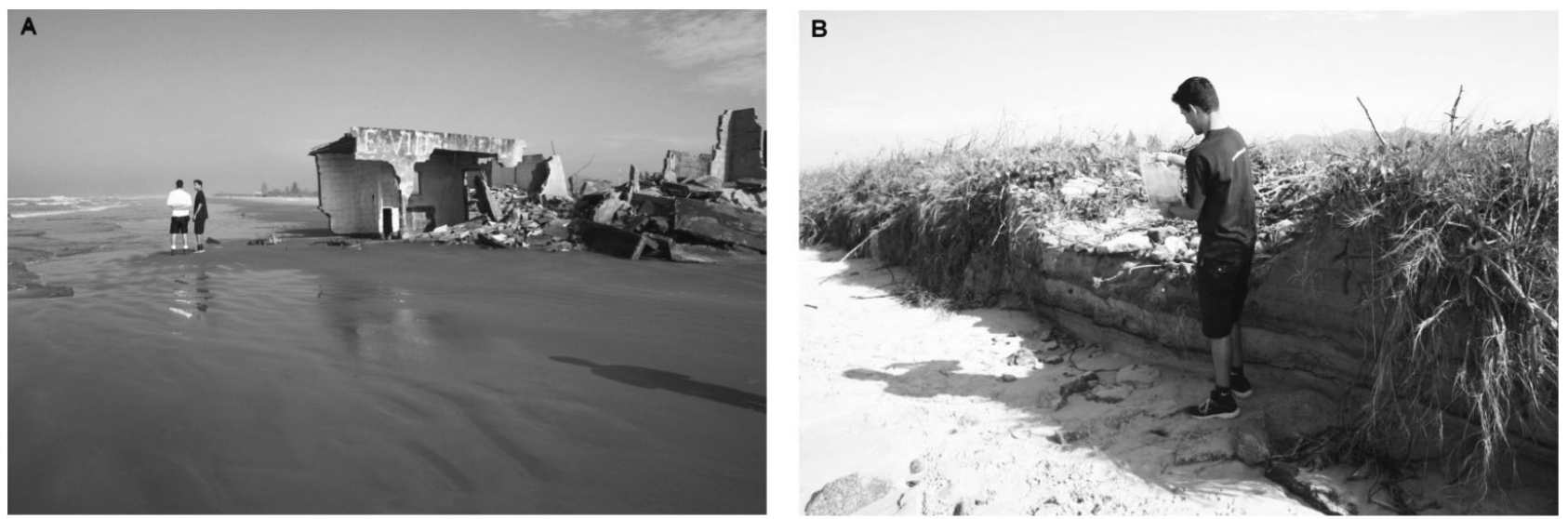

Figura 8. A. Erosão próxima ao extremo nordeste da praia de llha Comprida (distância 59 km no sentido SW-NE, zona correspondente à antiga projeção costeira), evidenciada pela presença de construções destruídas sobre a face da praia. B. Falésia viva imposta em terraço de duna frontal: evidência de erosão recente, a $60 \mathrm{~km}$ de distância ao longo da praia da llha Comprida, no sentido SW-NE, também na região do antigo esporão.
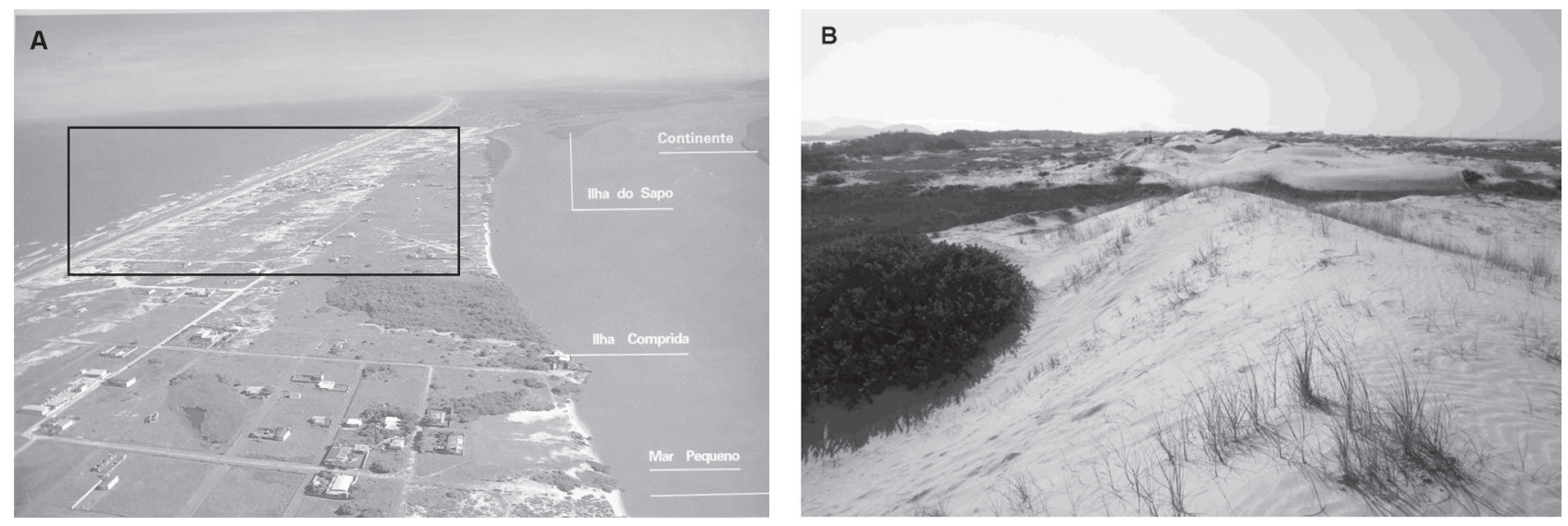

Figura 9. A. Vista aérea (para sudoeste) da região do campo de dunas ativo, próximo à extremidade nordeste da llha Comprida (fonte: Carneiro, 1995). B. Aspecto local do mesmo campo de dunas, a 6 km do canal de lcapara (distância $57 \mathrm{~km}$ em rumo SW para NE), e a cerca de $200 \mathrm{~m}$ da praia, em vista para nordeste.

gorda” rumo SE (tempos 1 e 2 na Figura 10). Na fase 2, haveria crescimento mais pronunciado para NE, tornando subordinada a componente de alargamento (rumo SE) da ilha (tempos 3 e 4 da mesma figura). Na fase 3, o crescimento para NE teria sido temporariamente interrompido pelo morro de Icapara, que funcionou como obstáculo para a corrente de deriva litorânea longitudinal e assim propiciou fase dominada por alargamento (tempos 5 a 7). Por fim, na fase 4, a "engorda” da ilha atingiu o ponto em que o morro de Icapara não mais funcionava como obstáculo para a corrente de deriva litorânea longitudinal. A barreira retomou assim seu crescimento rumo NE, como pode ser ob- servado hoje em dia com a migração da desembocadura de Icapara (tempo 8).

Nesse contexto, a extremidade nordeste da Ilha Comprida insere-se no período mais recente da fase 4 (tempo 8), a partir do qual retorna predomínio de seu crescimento longitudinal (para NE) sobre transversal (para SE). Conquanto se destaque seu crescimento rumo NE, a "engorda” transversal da ilha como um todo teve lugar, e é concordante com tendência de equilíbrio relativo na fase 4 entre os componentes de crescimento da barreira (Giannini et al., 2008, no prelo), embora a abertura do Valo Grande possa ser fator de incremento longitudinal. 

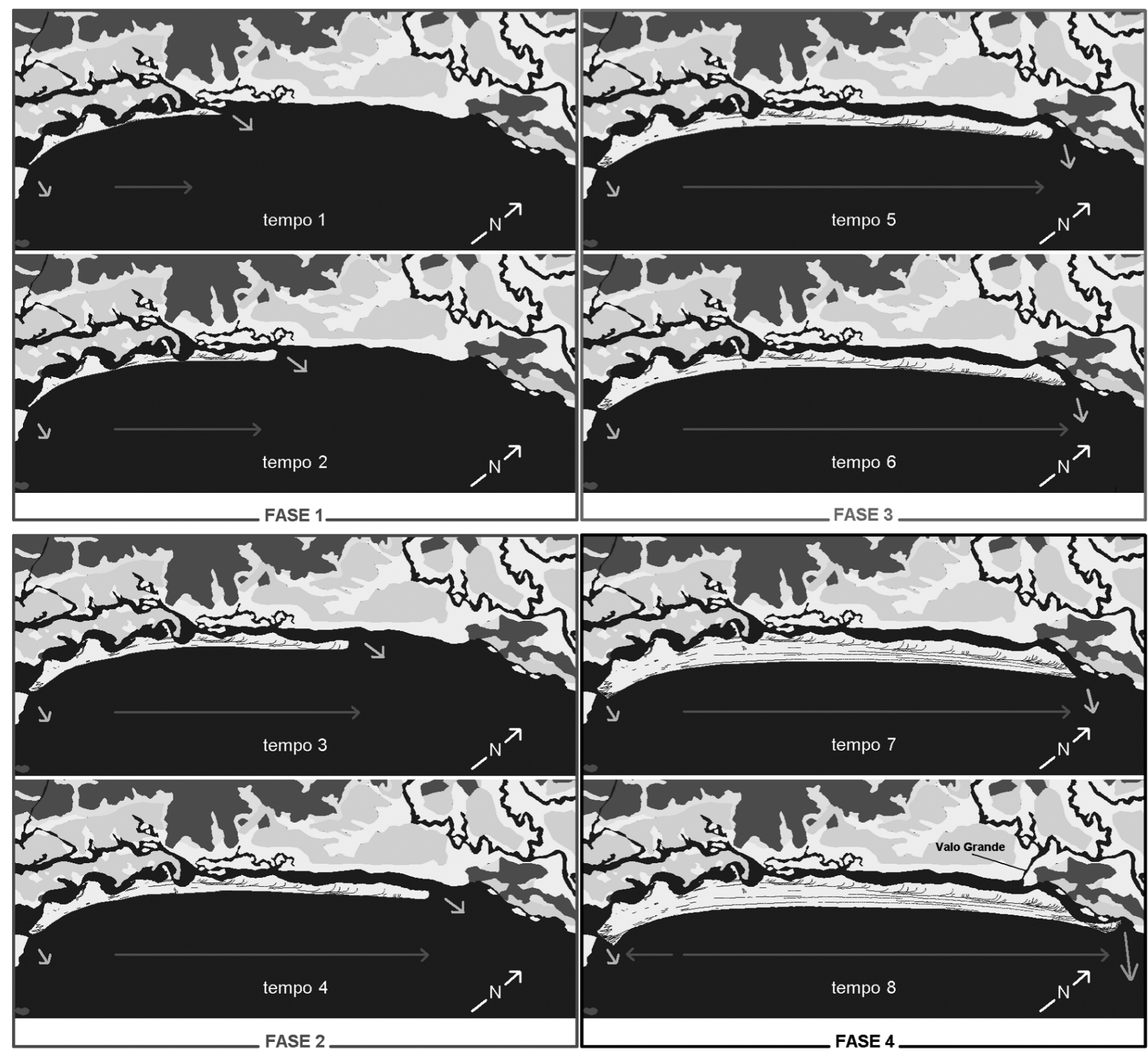

Figura 10. Modelo evolutivo de crescimento sedimentar da barreira de llha Comprida durante o Holoceno. Detalhado de Giannini et al. (2003a) e Guedes (2003).

\section{CONCLUSÕES}

A compilação de dados de registros históricos, cartas náuticas e mapas, além de análise fotointerpretativa, permitiram estabelecer modelo de desenvolvimento secular da ponta nordeste da Ilha Comprida. Por este modelo, verificase intensa morfodinâmica nessa região, incluindo variações de largura e comprimento da ilha, desaparecimento de feições (como a Praia do Leste e seus cordões litorâneos), surgimento de feições (como o campo de dunas transgressivo do km 57), e existência de feições intermitentes (como a "lagoa” Gapara e o esporão arenoso do km 59).

Historicamente, é destacada a influência da abertura do canal artificial do Valo Grande nas mudanças ocorridas na extremidade NE da Ilha Comprida desde então. Seu estabelecimento foi fator de incremento ao deslocamento do canal de Icapara nesse rumo (com conseqüente crescimento da barreira e erosão da praia do Leste), através do qual a ilha 
adquiriu cerca de $10 \%$ de seu tamanho atual em apenas 130 anos, enquanto o restante da ilha (antes do Valo Grande) aparentemente levou mais de 5.000 anos para ser construído (Giannini et al., 2003b; Giannini et al., 2008, no prelo).

Em adição, reforça e detalha o tempo 8 (fase 4) do modelo evolutivo de Giannini et al. (2003a) e Guedes (2003), de escala milenar, no qual há predomínio de transporte litorâneo (por correntes de deriva) para NE (Figura 10). Mostra também que esse padrão celular de transporte local voltado para NE, confirmado através das análises de distribuições granulométricas e mineralógicas, não se alterou de forma significativa, ao menos desde a formação da barreira.

\section{AGRADECIMENTOS}

Os autores agradecem a Elaine Aparecida da Silva Sinfrônio e Mariana Cristina Victorino (Labsed/USP) pela assistência na separação granulométrica das areias. Também agradecem o apoio financeiro da CAPES (bolsa de mestrado), do CNPq (bolsa de iniciação científica) e da FAPESP (projeto de pesquisa - Proc. 01/01732-8).

\section{REFERÊNCIAS BIBLIOGRÁFICAS}

ANGULO, R. J.; SOUZA, M. C. Relative variation curves in sea-level during the last 7,000 years in Brazil: a review. In: FLETCHER, C. H.; MATTHEWS, J. V. (Ed.). The non-steady state of the inner shelf and shoreline: coastal change on the time scale of decades to millennia in the Late Quaternary. In: INTERNATIONAL GEOLOGICAL CORRELATION PROGRAMME, 1993, Honolulu. Abstracts with Programs... Honolulu: IGCP, 1993. p. 31-24. v. 437.

BARCELLOS, R. L. Processo sedimentar atual e a distribuição da matéria orgânica sedimentar no sistema estuarino-lagunar de Cananéia-Iguape. 2005. 192 f. Tese (Doutorado) - Instituto Oceanográfico, Universidade de São Paulo, São Paulo. 2005. 2 v. 2 mapas.

BARCELOS, J. H. Sedimentação e subambientes deposicionais da ilha Comprida. 1975. 155 f. Dissertação (Mestrado) - Instituto de Geociências, Universidade de São Paulo, São Paulo. 1975. 2 v.

BENTZ, D. Os cordões litorâneos da planície de UnaJuréia, municípios de Peruíbe e Iguape, SP. 2004. 109 f. Dissertação (Mestrado) - Instituto de Geociências, Universidade de São Paulo, São Paulo. 2004. 1 v, 3 mapas.

BENTZ, D.; GIANNINI, P. C. F. Interpretação aerofotogeomorfológica da planície costeira de Una-Juréia, municípios de Peruíbe-Iguape, SP: modelo evolutivo e ori- gem da erosão na praia da Juréia. In: CONGRESSO DAASSOCIAÇÃO BRASILEIRA DE ESTUDOS DO QUATERNÁRIO, 9., 2003, Recife. Anais... Recife: ABEQUA, 2003. 5 p. v. 1.

BONETTI FILHO, J.; FURTADO, V. V. Modelo digital de terreno aplicado ao estudo de feições costeiras submersas no litoral sul do Estado de São Paulo. Geociências, São Paulo, v. 15, n. 2, p. 367-380, 1996.

CARNEIRO, A. G. Guia mar São Paulo. São Paulo: Grupo 1, 1995. 225p.

DAVIES, J. L. A morphogenic approach to world shorelines. Zeitschrift für Geomorphology, Mortensen Sonderheft, v. 8, p.127-142, 1964.

GAO, S.; COLLINS, M. Net sediment transport patterns inferred from grain size trends, based upon definition of “transport vectors”. Sedimentary Geology, Oxford, v. 81, p. 47-60, 1992.

GEOBRÁS ENGENHARIAE FUNDAÇÕES S. A. Complexo Valo Grande, Mar Pequeno e rio Ribeira de Iguape. São Paulo: Geobrás S/A, Engenharia e Fundações para o Serviço do Vale do Ribeira do Depto. de Águas e Energia Elétrica, SP. 1966. 2 v. (Relatório).

GIANNINI, P. C. F. Sedimentação quaternária na planície costeira de Peruíbe-Itanhaém (SP). 1987. 234 f. Dissertação (Mestrado) - Instituto de Geociências, Universidade de São Paulo, São Paulo. 1987. 2 v. 3 mapas.

GIANNINI, P. C. F. Sistemas deposicionais eólicos no quaternário costeiro do Brasil. 2007. 205 f. Tese (Livredocência) - Instituto de Geociências, Universidade de São Paulo, São Paulo, 2007. 1 v.

GIANNINI, P. C. F.; ANGULO, R. J.; SOUZA, M. C.; KOGUT, J. S. Evidências de um padrão celular de correntes de deriva litorânea na costa leste da ilha do Mel (PR). In: CONGRESSO DA ASSOCIAÇÃO BRASILEIRA DE ESTUDOS DO QUATERNÁRIO, 5., 1995, Niterói. Anais... Niterói: ABEQUA, 1995. p. 120-127.

GIANNINI, P. C. F.; GUEDES, C. C. F.; ANGULO, R. J.; ASSINE, M. L.; SOUZA, M. C.; MORI, E. K. Geometria de cordões litorâneos e espaço de acomodação sedimentar na ilha Comprida, litoral sul paulista: modelo baseado em aerofotointerpretação. In: CONGRESSO DAASSOCIAÇÃO BRASILEIRADE ESTUDOS DO QUATERNÁRIO, 9., 2003a, Recife. Anais... Recife: ABEQUA, 2003a. 5 p. (CD-ROM). 
GIANNINI, P. C. F.; GUEDES, C. C. F.; ASSINE, M. L.; ANGULO, R. J.; SOUZA, M. C.; PESSENDA, L. C. R.; TATUMI, S. H. Variação transversal e longitudinal de propriedades sedimentológicas nos cordões litorâneos da ilha Comprida, litoral sul paulista. In: CONGRESSO DAASSOCIAÇÃO BRASILEIRA DE ESTUDOS DO QUATERNÁRIO, 9., 2003b, Recife. Anais... Recife: ABEQUA, $2003 \mathrm{~b}$. 7 p. (CR-ROM).

GIANNINI, P. C. F.; GUEDES, C. C. F.; NASCIMENTO JR., D. R.; TANAKA, A. P. B.; ANGULO, R. J.; ASSINE, M. L.; SOUZA, M. C. Sedimentology and morphologic evolution of the Ilha Comprida Barrier System, southern São Paulo coast. In: DILLENBURG, S. R.; HESP, P. Geology of the Brazilian coastal barriers. Oxford: Lecture Notes in Earth Sciences/Springer-Verlag, 2008. chap. 3. (no prelo).

GUEDES, C. C. F. Os cordões litorâneos e as dunas eólicas da Ilha Comprida, Estado de São Paulo. 2003. 54 f. Monografia (Trabalho de Formatura) - Instituto de Geociências, Universidade de São Paulo, São Paulo. 1 v.

HARARI, J.; FRANÇA, C. A. S.; CAMARGO, R. Variabilidade de longo termo de componentes de marés e do nível médio do mar na costa brasileira. Afro-America Gloss News, v. 8, n. 1, 2004.

HUBERT, J. F. A zircon-tourmaline-rutile maturity index and the dependence of the composition of heavy mineral assemblages with the gross composition and texture of sandstones. Journal of Sedimentary Petrology, v. 32, n. 3, p. 440-450, 1962.

McLAREN, P.; BOWLES, D. The effects of sediment transport on grain-size distributions. Journal of Sedimentary Petrology, v. 55, n. 4, p. 457-470, 1985.

MESQUITA, A. R.; HARARI, J. Tides and tide gauges of Cananéia and Ubatuba - Brazil (Lat. 24º ). São Paulo: Instituto Oceanográfico/Universidade de São Paulo, 1983. p. 1-14. (Relatório, 11).

NASCIMENTO Jr., D. R. Morfologia e sedimentologia ao longo do sistema praia - duna frontal de Ilha Comprida, SP. 2006, 136 f. Dissertação (Mestrado) - Instituto de Geociências, Universidade de São Paulo, São Paulo. 2006.

PETRI, S.; SUGUIO, K. Some aspects of the Neocenozoic sedimentation in the Cananéia-Iguape lagoonal region, São Paulo, Brasil. Estudos Sedimentológicos, v. 1, n. 1, p. 25-33, 1973.
PETTIJOHN, F. J. Sedimentary rocks. 2. ed. London: Harper and Bros., 1957. 718 p.

PISETTA, M. Transporte de sedimentos por suspensão no sistema estuarino-lagunar de Cananéia-Iguape (SP). 2006. 179 f. Dissertação (Mestrado) - Instituto Oceanográfico, Universidade de São Paulo, São Paulo, 2006.

TELES, A. P. S. S. A evolução geológica quaternária e a influência do Valo Grande na dinâmica sedimentar da área de Iguape, São Paulo. 1997. 98 f. Dissertação (Mestrado) Instituto Oceanográfico, Universidade de São Paulo, São Paulo, 1997. 1 v. 1 mapa.

TESSLER, M. G. Sedimentação atual na região lagunar de Cananéia-Iguape, estado de São Paulo. 1982. 169 f. Dissertação (Mestrado) - Instituto de Geociências, Universidade de São Paulo, São Paulo, 1982. 2 v.

TESSLER, M. G. Dinâmica sedimentar quaternária no litoral sul paulista, estado de São Paulo. 1988.

277 f. Tese (Doutorado) - Instituto de Geociências, Universidade de São Paulo, São Paulo, 1988. 1 v. 1 mapa.

SAWAKUCHI, A. O. Morfologia e simulação numérica de campos de dunas costeiros: estudo baseado em exemplos brasileiros. 2006. 316 f. Tese (Doutorado) - Instituto de Geociências, Universidade de São Paulo, São Paulo, 2006. 1 v.

SUGUIO, K.; PETRI, S. Stratigraphy of the Iguape-Cananéia lagoonal region sedimentary deposits, São Paulo state, Brazil. Part I: field observations and grain size analysis. Boletim do Instituto de Geociências. São Paulo, v. 4, p. 1-20, 1973.

SUGUIO, K.; MARTIN, L. Formações quaternárias marinhas do litoral paulista e sul fluminense. In: INTERNATIONAL SYMPOSIUM ON COASTAL EVOLUTION IN THE QUATERNARY, 1., 1978a. São Paulo. Special Publication... São Paulo: IGCB/IG-USP/SBG, 1978. 55 p.

SUGUIO, K.; MARTIN, L. Mapas geológicos da planície costeira do estado de São Paulo e sul do Rio de Janeiro. São Paulo: DAEE/Secretaria de Obras e Meio Ambiente, 1978b. 2 mapas. Escala 1:100.000. 